\title{
Clinical efficacy and tolerability of mometasone furoate nasal spray in perennial allergic rhinitis patients : an open multicentre study
}

\author{
Iwan Darmansjah, "Arini Setiawati, "Iwin Sumarman, ${ }^{f}$ Mulyarjo, ${ }^{\dagger}$ Elise Kasakeyan, ${ }^{0}$ Nur Akbar Aroeman ${ }^{f}$. \\ Roestiniadi Djoko Soemantri ${ }^{\ddagger}$, Nina Irawati ${ }^{0}$. Tety H. Rahim ${ }^{f}$
}

\begin{abstract}
Abstrak
Monetason furoat (MF) semprot hidang (larutan air) telah ditunjukkan efeksif dan dapat ditolenansi dengan baik pada pengobatan rimitis alergik sepanjang tahun (RAST). Namum senua studi terieliut ditakukan di Kanada, Amerika Serikat, dan Eropa. Karena adanya pertecdaan craca, maka dinasakan perlu untuk melaknkan studi di negara tropis. Uji klinik ini bertujuan untuk menilai efektivitas klinik dun folerabilitas MF semprot hidung untuk mengobatt RAST di negara tropis. Studi ini terbuka tanpa pembanding, dilakukan pada 3 senter seluma 4 minggu dan mengikutsertakan penderta berobat jakan umur 12 sampai 60 tahun dengan RAST sedang sampai benat, seniuk minimat 2 tahun. Penderita alergik terhadap setidaknya I alergen utama RAST yang dipastikan dengan tes kalit. Mereka nemptinuai total skor gejala nasal (TSCN) $\geq 6$ dan skor kongesti nasal (SKN) $\geq 2$ pada $\geq 3$ kali pengukuran sebelum kunjungan awal dan pada kedua kunjungan saringan dan awal. Penderita yang mememhi syarat mendapat MF semprol hidung pada kunjungan awal, dan menggunakan $200 \mathrm{Hg}$ mametason setiap pagi selama 4 minggu. Panameter efektivitas klinis yang utama adulah persentase penurunan TSGN dari kondisi awal (jra pengobatan). Dari 100 penderita yang mementhi sjarat, semuanya menyelesaikan studi 4 minggu ini. TSGN berdasarkan penilaias penderita (jtantah skar 3 pagi terakhir) menuran $60.9 \%$ dari skor awal ( $p<0.0001$ ) pada minggu 2 dan memuran $73.6 \%(p<0.0001)$ pada minggu 4. Penuratan TSGN berdasarkan penilatan dokter peneliti $(61.7 \%$ pada minggu 2 dan $77.8 \%$ pada mingsa 4) lebih tinggi dibutingkan penuranan pada studi-studi sebelumnya (43 \% dan 51 \% pada minggu $2,52 \%$ dan 54 \% pada minegu 4). Kecenderimgan yang sama terlihat untuk shor kongesti nasal (SKN), skor gejala-gejala laimnya, total skor gejala (nasal + non nasal), dan efekivitas klinik. Gejala-gejala di petang hari berkarang sama besarnya dengan di pagi hari. Tidak ada penderita yang menarik diri dari penelitian akibut efek samping. Dari penelitian ini disimpulkan bahwa MF semprot hidang, pada dosis $200 \mu \mathrm{g}$ sekali sehari di pagi har untuk pengobatan RAST sedang sampai benat di negara tropis, secara klinis efektif unituk mengatasi gejala-gejala RAST selana 24 jam, dan dapat ditoleransi dengan baik. (Med J Indones 2002; II; 69-80)
\end{abstract}

\begin{abstract}
Mometasone furoate (MIF) aqueous nasal spray has been shown to be effective and well-toierated in the treatment of perennial allergic rhinitis (PAR). All of the studies, however, have been conducted in Canada, UK, and Eunope. Therefore, a bridging study is warranted in sies of the different climatic conditians in tropical contries. To evaluate the clinical efficacy and tolerability of MF aqueous nasal spnay in the treatment of PAR in a tropical country. This study was an open, non-comparative, 4-week, 3-centre trial in outpatients of 12 to 60 ycars with moderate to severe PAR of at least 2 ycars duration. Patients were allergic to at least one major PAR allergen. confirmed by skin prick. iest. Thry had lotal nasal symprom score (TNSS) of $\geq 6$ and nasal congeston score (NCS) of $\geq 2$ on $\geq 3$ diary time points prior to baseline visit and at both screening and baseline visits. Eligible patients received MF aqueora nasal spray at baseline visit, and administered $200 \mu \mathrm{g}$ montetasone orry morning for 4 wecks. The primany clinical efficacy parameter was the mean percentage reduction of TNSS from baseline. Of 100 eligible petients, all completed this 4-week trial. The patient-evaluated TNSS (stum of the last 3 momings) decreased significantly from baseline with a mean rediction of $60.9 \mathrm{~g}(p<0.0001)$ at week-2 and $73.6 \%(p<0.0001)$ at week-4. 77e mean reductions in plsysician-rated TNSS $(61.7 \%$ at week. 2 and $77.8 \%$ at week-4) were higher than those in the previous studies (43 \% and 5$)$ \% at week-2, $52 \%$ and $54 \%$ at week 4 ). Similar trends were observed for na,sal congestion score (NCS), other individual symptoms, total symptoms, and clinical fficacy rates. Evening symptoms were reduced similarty as moming symptoms. There was no withirawal due to adverse event. MF aqueous nasal spray, at a dose of $200 \mathrm{Hg}$ ance daily in the moming for the treatment of moderate to severe PAR in a tropical cotuntry, was elinically effective with 24-hour control of PAR symptoms, and was well tolerated. (Med J Indones 2002; 11: 69-80)
\end{abstract}

Keywords: mometasone furoate, nasal spray, perennial allergic rhinitis.

- Clintical Trial Center. Medical Factuld: Untiversity of Indonesia,

Jakarta, Indonesia

Ear, Nose and Throat Deparment, Medical Faculty, University of Padjadjaran/Hasan Sadikin Hospital, Bandung, Indonesia

I ENT Department, Medical Faculty, Universiry of Airlanggal Dr. Soetomo General Hospital, Surabaya, Indonesia

* ENT Department, Medical Faculty, University of Indonesial Dr. Cipro Mangunkusumo General Hospital, Jakarta, Indonesia 
Mometasone furoate (MF) is a synthetic glucocorticoid, the furoate ester of chloro, methylbeclomethasone. MF nasal spray is an aqueous suspension of MF in a metered-dose spray unit containing $50 \mathrm{mg}$ of mometasone base / actuation. ' MF has anti-allergic and anti-inflaminatory activities based on its ability to inhibit the release of leukotrienes from leukocytes of allergic patients. ${ }^{2}$ It has been marketed in many countries, including Indonesia, for the treatment of seasonal and perennial allergic rhinitis.

Perennial allergic rhinitis (PAR) is a continuous inflammatory response of the upper airway and eyes to exposure of allergens such as dust, mites, cat and dog dander, etc. The symptoms of PAR consist primarily of nasal symptoms (congestion, discharge, itching and sneezing) with involvement of the eyes and ears. These symptoms, especially nasal congestion, may be extremely troublesome for many patients and may cause significant impairment of their quality of life. ${ }^{3}$ In addition to allergen avoidance, nasal corticosteroids have become well established as a first-line treatment for patients with moderate to severe PAR. ${ }^{4}$ The use of nasal steroids for PAR tends to be chronic but intermittent, i.e. at the time of worsening of symptoms.

MF, administered as an aquous nasal spray, has negligible $(\leq 0.1 \%)$ systemic bio-availability (generally undetectable in plasma) due to its small quantities used, poor absorption, and extensive first-pass hepatic metabolism. ${ }^{2}$ Therefore, there was no evidence of HPAaxis suppression following long-term use in PAR for periods of up to one year. ${ }^{5} \mathrm{MF}$ nasal spray is effective in a once-daily dosage regimen and the usual recommended dose for the treatment of PAR is $200 \mu \mathrm{g} /$ day. ${ }^{1}$

Clinical studies showing safety, efficacy and tolerability of MF nasal spray were conducted in Canada, UK, Europe, and the US. Therefore, a bridging study is warranted in view of the different climatic conditions in tropical countries, at least to show the efficacy and tolerability in a short-term study. The objective of the present study was to evaluate the clinical efficacy and tolerability of MF nasal spray in moderate to severe PAR patients in a tropical country like Indonesia in an open non-comparative 4-week study.

\section{METHODS}

\section{Patients}

Outpatients of either sex, aged between 12 to 60 years with moderate to severe perennial allergic rhinitis of at least 2 years were recruited into the study. They were patients with skin test positive (prick test) to a major allergen for PAR (house dust, house dust mite, cockroach, mold, cat and dog fur or chicken feather), with a score of 3 or 4 (moderately severe or severe). They had a combined nasal symptom score (nasal congestion, nasal discharge, sneezing and nasal itching) of at least 6 and nasal congestion score of at least 2 on minimally 3 diary time points prior to the baseline visit as well as at both the screening and the baseline visits. Patients had agreed to adhere to the dosing and visit schedules, and to record symptom severity scores, medication times, concomitant medications, and adverse event(s) on the diary cards provided, and to sign the written informed consent.

Excluded from the study were patients with sinusitis, nasal polyps, marked septal deviation or any other structural abnormality that significantly interferes with nasal airflow, and also patients with recent nasal septum ulcers, nasal surgery or nasal trauma before it healed completely. Also excluded were patients with significant renal, hepatic, neurologic, cardiovascular, hematologic, metabolic, cerebrovascular, respiratory, gastrointestinal, or other significant medical illness or disorder, patients with a history of psychosis, antagonistic personality, poor motivation, hypochondrosis, or any other emotional or intellectual problems. Other exclusions were pregnant women, nursing mothers, o women of childbearing potential without acceptabl. method of birth control, patients using any investigational product within 30 days, or any of the prohibited medications, or patients who had participated in more than 2 clinical trials in allergic rhinitis within the past year.

\section{Study design and procedure}

This study was an open, noncomparative, multicentre trial, performed in outpatients with moderate to severe perennial allergic rhinitis. Three centres, i.e. the outpatient clinics of the ENT Departments of the Government Medical Faculties in Jakarta, Bandung, and Surabaya participated in the present study. The study protocol was approved by the Ethics Committee of the respective institutions, and was conducted it. compliance with Good Clinical Practice. Mometasone furoate (Nasonex ${ }^{8}$ ) nasal spray, in metered-dose manual pump spray units (120 metered doses per spray unit) were provided by Schering Plough Indonesia, imported from Kenilworth, New Jersey, USA.

Signs and symptoms of PAR were divided into nasal symptoms and non-nasal symptoms. Nasal symptoms 
consisted of 4 symptoms : nasal congestion, nasal discharge, sneezing and nasal itching, while non-nasal symptoms consisted of 2 symptoms : itching of ears, palate and/or throat, and itching, watery, red eyes. The severity of each symptom was scored 0 to 3 where $0=$ none (no sign / symptom evident), $1=$ mild (sign / symptom clearly present, but easily tolerated), $2=$ moderate (definite awareness of sign/symptom, bothersome but tolerable), $3=$ severe $(\mathrm{sign} / \mathrm{symptom}$ hard to tolerate, interfere with activities of daily living and/or sleeping). Signs and symptoms of PAR were scored by the investigator at each visit : screening (day -3 to 0 ), baseline (day 1), follow-up I (day 15) and follow-up II (day 29). These signs and symptoms of PAR were also scored by the patients themselves and recorded every morning and evening on the diary cards provided.

Each eligible patient received one new, sealed container of Nasonex® nasal spray at the baseline visit. It is a metered-dose manual-pump spray unit, which requires 5-7 times priming before it delivers 50 $\mu \mathrm{g}$ mometasone base/actuation. The patients were instructed to take 2 sprays per nostril (total $200 \mu \mathrm{g}$ mometasone) every morning upon arising. The first dose was taken at the baseline visit (day 1) in front of the investigator, demonstrating the correct delivery technique of the medication.

Concomitant treatment with other corticosteroids, antihistamines, ketotifen, decongestants, nasal saline, ipratropium intranasal, herbal medications for allergies, eye washes / drops, ophthalmic NSAIDs, some antihypertensives (methyldopa, reserpine, guanethidine), systemic antibiotics, investigational medications, and tricyclic / tetracyclic antidepressants were not allowed. The following medications were permitted before and during the trial : OTC pain medication not containing anti-rhinitis / anti-allergy, low-dose aspirin as antiplatelet, dermatological corticosteroids, topical antibiotics; also stable dosage of a $\beta 2$-agonist or theophylline for asthma, hormone replacement therapy, or thyroid replacement therapy. Patients could be withdrawn from the study for either safety, efficacy or compliance reason. Patients may withdraw from the study at any time and the reasons for this were recorded. Any adverse events reported were noted in the case report form.

\section{Assessments}

The primary clinical efficacy variable in the present study was the total nasal symptom score (TNSS). It was defined as the sum of severity scores of the 4 nasal symptoms (nasal congestion, nasal discharge, sneezing and nasal itching). The severity of each symptom was scored 0 to 3 (see "Study procedure" above), making a maximum possible score of 12 for TNSS. Since physician evaluation was done during scheduled patient visit in the morning, the patientevaluated TNSS selected for analysis was the sum of the last 3 mornings TNSS prior to the scheduled visit (a maximum possible score of 36) in order to obtain comparable conditions.

The secondary clinical efficacy variables were nasal congestion score (NCS), total symptom score (TSS), and the individual symptom score (other than NCS), evaluated by both the physician and the patient (the last 3 mornings), and the last 3 evenings TNSS, NCS, and TSS, evaluated by the patient. TSS was the sum of severity scores of all symptoms (4 nasal symptoms and 2 non-nasal symptoms).

The clinical efficacy was rated based on the TNSS and the NCS as complete relief (CR), marked relief $(\mathrm{MaR})$, moderate relief (MoR), slight relief (SR), and treatment failure (TF). CR was defined as reaching $13 \%$ or less of the baseline value, MaR between 14 and $35 \%$, MoR between 36 and $70 \%$, SR between 71 and $90 \%$, and TF more than $90 \%$ of the baseline value. $\mathrm{CR}$ and $\mathrm{MaR}$ combined was considered as the desired efficacy, whereas $\mathrm{CR}, \mathrm{MaR}$ and $\mathrm{MoR}$ combined was considered as the success rate.

The primary clinical efficacy parameter was the mean percentage reduction of TNSS from baseline. The secondary clinical efficacy parameters were the mean percentage reduction of NCS from baseline; the clinical efficacy rates; the mean percentage reduction from baseline of TSS, the individual symptom score, and the evening patient TNSS, NCS, and TSS.

\section{Data analysis}

Besides descriptive statistics, paired statistical tests were used to compare the scores before and after treatment : paired ANOVA for TNSS and TSS followed by paired-t test for pairwise comparisons, and Friedman's test for NCS and other individual symptom score followed by Wilcoxon matched-pairs test. The clinical efficacy rates based on TNSS and NCS were compared, also between patient evaluation and physician evaluation, using McNemar test. Each 
statistical test was pertormed at 0.05 (2-tailed) level of significance with no adjustment for multiple comparisons:

Adverse events, whether considered related or unrelated to the study drug by the investigator, were listed with their respective incidences.

\section{RESULTS}

\section{Patients}

One hundred and three patients were screened and 100 patients were eligible to be included in the study, of which 30 patients were from Jakarta, 35 patients from Bandung, and another 35 patients from Surabaya. There were almost as many male patients as females and about two thirds were in the age group of 21 to 35 years with a mean of 27.3 years and a median 25 years. The mean body weight was $52.8 \mathrm{~kg}$. The mean duration of PAR was 6.2 years. The detailed patient demographics is given in Table 1 .

All qualified patients had positive skin tests with moderately severe to severe degree) to at least one major allergen for PAR (usually to more than one allergen). Among 100 patients, 84 patients were allergic to house dust, 84 patients (may not be the same patients) to house dust mite, 66 to cockroach, 24 to mold, 13 to cat fur, 47 to dog fur, and 10 patients to chicken feather.
Table 1. Demographics of patients at baseline

\begin{tabular}{|c|c|c|}
\hline \multicolumn{2}{|l|}{ Total no of patients } & \multirow{2}{*}{$\begin{array}{l}100 \\
49 / 51\end{array}$} \\
\hline Gender & : Male / Female & \\
\hline Age & $\begin{array}{l}12-20 \text { yrs } \\
21-35 \text { yrs } \\
36-50 \text { yrs } \\
51-60 \text { yrs } \\
\text { Mean } \\
\text { Median } \\
\text { Range }\end{array}$ & $\begin{array}{l}19 \\
66 \\
11 \\
4 \\
27.3 \text { yrs } \\
25 \text { yrs } \\
13-58 \text { yrs }\end{array}$ \\
\hline Weight & $\begin{array}{l}\text { Mean } \\
\text { Range }\end{array}$ & $\begin{array}{l}52.8 \mathrm{~kg} \\
36-87 \mathrm{~kg}\end{array}$ \\
\hline Duration of PAR & $\begin{array}{l}\text { Mean } \\
\text { Median } \\
\text { Mode } \\
\text { Range }\end{array}$ & $\begin{array}{l}6.2 \text { yrs } \\
5 \text { yrs } \\
2 \text { yrs } \\
2-37 \text { yrs }\end{array}$ \\
\hline $\begin{array}{l}\text { TNSS at haseline } \\
\text { (physician-rated) }\end{array}$ & $\begin{array}{l}\text { : Mean } \\
\text { Range }\end{array}$ & $\begin{array}{l}8.1 \\
6-12\end{array}$ \\
\hline
\end{tabular}

\section{Efficacy}

All eligible pattents completed this 4-week trial.

The patient-evaluated TNSS (sum of the last 3 momings) decreased significantly from a mean of 23.5 at baseline to 9.2 at week-2 (a mean reduction of $60.9 \%$; $<<$ 0,0001 ), and to 6.2 at week 4 (a mean reduction of $73.6 \% ; p<0.0001$ ). The physician-evaluated TNSS (during the morning visit) showed a similar trend, it decreased significantly from an average of 8.1 at week0 to 3.1 after 2 weeks (a mean reduction of $61.7 \%: \mathrm{p}<$ 0.0001 ) and to 1.8 after 4 weeks of treatment (at mean reduction of $77.8 \% ; p<0.0001$ ) (Table 2 ).

Tuble 2. Total nasal symptom score (TNSS) before and after treatment

\begin{tabular}{|c|c|c|c|c|c|c|c|c|}
\hline & & \multirow[b]{2}{*}{ Baseline } & \multirow[b]{2}{*}{ Week-2 } & \multirow[b]{2}{*}{ Week-4 } & \multicolumn{2}{|c|}{ \% reduction from baseline } & \multirow[b]{2}{*}{ Paired-t } & \multirow[b]{2}{*}{$p$ (2-tailed $)$} \\
\hline & & & & & Week-2 & Week-4 & & \\
\hline \multirow[t]{6}{*}{ a) } & \multicolumn{6}{|c|}{ Patient evaluation (Sum of the last 3 momings) } & \multirow{6}{*}{$\begin{array}{l}-16.4^{*} \\
-21.1^{* *} \\
-4.57 \ldots \ldots\end{array}$} & \multirow{6}{*}{$\begin{array}{l}<0.0001^{*} \\
<0.0001^{*} \\
<0.0001^{* *}\end{array}$} \\
\hline & Mean & 23.5 & 9.2 & 6.2 & -60.9 & -73.6 & & \\
\hline & $\mathrm{SD}$ & 5.57 & 8.20 & 6.32 & 33.22 & 27,84 & & \\
\hline & Median & 23 & 7 & 5 & -68.3 & -79.0 & & \\
\hline & Mode & 18 & 0 & 0 & -100 & -100 & & \\
\hline & Range & $13-36$ & $0-36$ & $0-28$ & $-100 \rightarrow 26.7$ & $-100 \rightarrow 26.7$ & & \\
\hline \multirow[t]{6}{*}{ b) } & \multicolumn{6}{|c|}{ Physician evaluation (At the morning visit) } & \multirow{6}{*}{$\begin{array}{l}+17.9 * \\
-25.7 * 0 \\
-7.31 * \cdots\end{array}$} & \multirow{6}{*}{$\begin{array}{l}<0.0001^{*} \\
<0.0001^{* *} \\
<0.0001^{* * *}\end{array}$} \\
\hline & Mean & 8.1 & 3.1 & 1.8 & -61.7 & -77.8 & & \\
\hline & $\mathrm{SD}$ & 1.60 & 2.42 & 1.99 & 30.18 & 25.71 & & \\
\hline & Median & 8 & 3 & 1 & $.65,2$ & -86.6 & & \\
\hline & Mode & 8 & 1 & 0 & -100 & -100 & & \\
\hline & Range & $6-12$ & $0-10$ & $0-8$ & $-100 \rightarrow 16.7$ & $-100 \rightarrow 16.7$ & & \\
\hline
\end{tabular}

- Week-2 vs Baseline

-. Weck-4 vs Baseline

*.. Week-4 vs Week-2 
Table 3 shows improvement of the nasal congestion. Patient-evaluated NCS on the last 3 consequtive mornings showed significant reductions at week- 2 and week -4 , while physician-evaluated NCS showed similar reductions.

The clinical efficacy rates based on TNSS are depicted in Table 4. After 2 weeks of treatment, evaluation by both the patient and the physician gave similar results. After 4 weeks of treatment, significantly more patients were rated as complete relief by the physician than by the patient ( 50 vs $37: \mathrm{p}=0.007$ ), while the desired efficacy and the success rates were similar.
The clinical efficacy rates based on NCS can be seen in Table 5. Improvement at week-2, as evaluated by either the patient or the physician, did not differ significantly, although the desired efficacy showed noticable difference ( 47 vs $37: p=0.10$ ). At week -4 . the number of patients rated as complete relief by the physician were significantly higher than those by the patient ( 52 vs $40 ; p=0.012$ ); the desired efficacy and the success rate were the same.

Table 6 shows the clinical efficacy rates based on patient evaluation. At both week-2 and week-4, clinical efficacy rated by the patient based on either

Table 3. Nasal congestion score (NCS) before and after treatment

\begin{tabular}{|c|c|c|c|c|c|c|c|c|}
\hline & & \multicolumn{7}{|c|}{ of reduction from baseline } \\
\hline & & Baseline & Week-2 & Week-4 & Week-2 & Week-4 & $\mathbf{Z}$ & p (2-tailed) \\
\hline \multirow[t]{5}{*}{ a) } & \multicolumn{8}{|c|}{ Patient evaluation (Sum of the last 3 momings) } \\
\hline & Mean & 6.69 & $2: 85$ & 2.05 & -57.4 & -69.4 & $-8.09^{*}$ & $<0.0001^{*}$ \\
\hline & Median & 6 & 3 & 2 & -62.5 & -66.7 & $-8.41^{* *}$ & $<0,0001^{*}$ \\
\hline & Mode & 6 & 0 & 0 & -100 & -100 & $-3.67^{* * *}$ & $<0.001 * * . *$ \\
\hline & Range & $2-9$ & $0-9$ & $0 \rightarrow 9$ & $-100 \rightarrow 33.3$ & $-100 \rightarrow 100$ & & \\
\hline \multirow[t]{5}{*}{ b) } & \multicolumn{8}{|c|}{ Physician evaluation (At the moming visit) } \\
\hline & Mean & 2.28 & 1.05 & 0.6 & -53.9 & $-73,7$ & $-7.81^{*}$ & $<0.0001^{*}$ \\
\hline & Median & 2 & 1 & 0 & -50 & -100 & $-8.45^{* *}$ & $<0.0001^{* *}$ \\
\hline & Mode: & 2 & 1 & 0 & -50 & $\cdot 100$ & $-5.63 * * * *$ & $<0,0001^{* * *}$ \\
\hline & Range & $2-3$ & $0-3$ & $0-3$ & $-100 \rightarrow 0$ & $-100 \rightarrow 0$ & & \\
\hline
\end{tabular}

- Weck-2 vs Baseline $\quad \cdots$ Week-4 vs Baseline $\quad * * *$ Week-4 vs Week-2

Table 4, Clinical efficacy rates based on total nasal symptom score (TNSS)

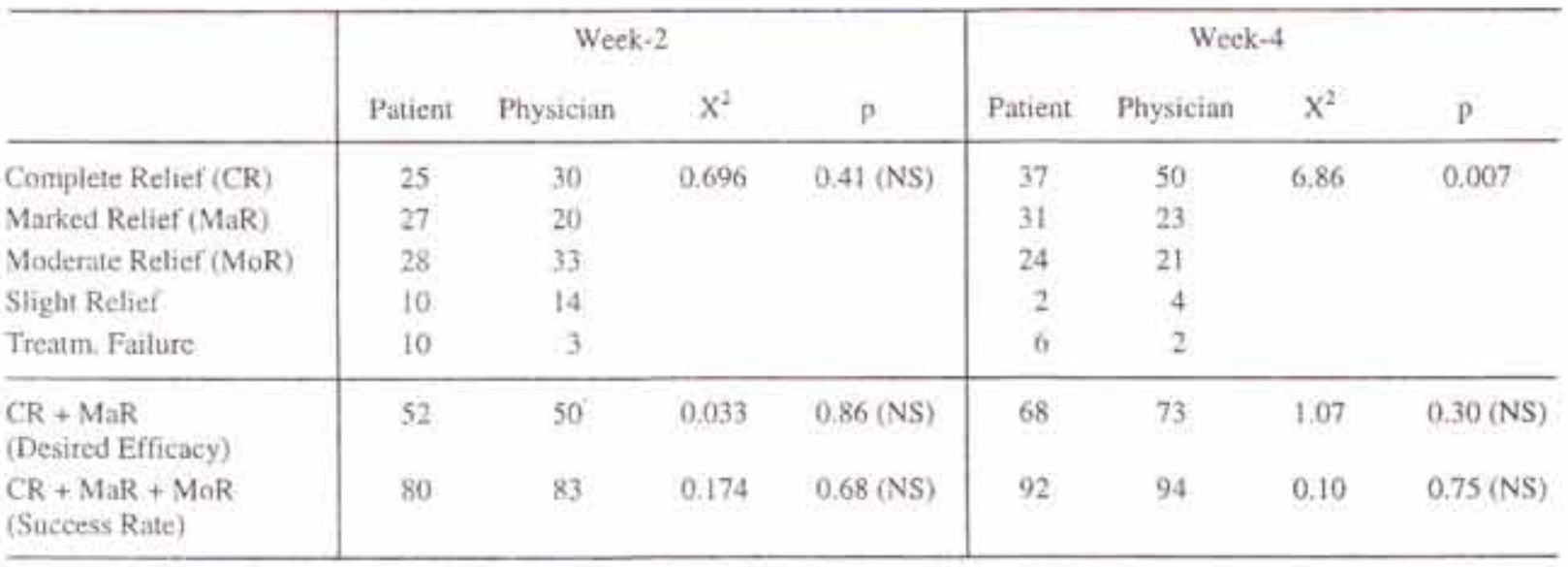

NS = Not Significant 
Table 5. Clinical efficacy rates based on nasal congestion score (NCS)

\begin{tabular}{|c|c|c|c|c|c|c|c|c|}
\hline & \multicolumn{4}{|c|}{ Week-2 } & \multicolumn{4}{|c|}{ Week-4 } \\
\hline & Patient & Physician & $\mathrm{X}^{2}$ & p & Patient & Physician & $x^{2}$ & $\mathrm{p}$ \\
\hline Complete Relief (CR) & 30 & 27 & 0.190 & 0.66 (NS) & 40 & 52 & 6.05 & 0.012 \\
\hline Marked Relief (MaR) & 17 & 10 & & & & 19 & 9 & \\
\hline Moderate Relief (MoR) & 30 & 40 & & & & 28 & 30 & \\
\hline Slight Relief & 7 & - & & & 6 & $\cdots$ & & \\
\hline Treatm. Failure & 16 & 23 & & & 7 & 9 & & \\
\hline $\begin{array}{l}\mathrm{CR}+\mathrm{MaR} \\
\text { (Desired Efficacy) }\end{array}$ & 47 & 37 & 2.70 & 0.10 (NS) & 59 & 61 & 0.045 & 0.83 (NS) \\
\hline $\begin{array}{l}\mathrm{CR}+\mathrm{MaR}+\mathrm{MoR} \\
\text { (Success Rate) }\end{array}$ & 77 & 77 & 0.00 & 1.0 (NS) & 87 & 91 & 0.90 & 0.34 (NS) \\
\hline
\end{tabular}

$\mathrm{NS}=$ Not Significant

Table 6 . Clinical efficacy rates based on patient evaluation

\begin{tabular}{|c|c|c|c|c|c|c|c|c|}
\hline & \multicolumn{4}{|c|}{ Week-2 } & \multicolumn{4}{|c|}{ Week-4 } \\
\hline & TNSS & NCS & $X^{2}$ & p & TNSS & NCS & $x^{2}$ & $\mathrm{p}$ \\
\hline Complete Relief (CR) & 25 & 30 & 1.23 & 0.27 (NS) & 37 & 40 & 0.364 & 0.55 (NS) \\
\hline Marked Relief (MaR) & 27 & 17 & & & 31 & 19 & & \\
\hline Moderate Relief (MoR) & 28 & 30 & & & 24 & 28 & & \\
\hline Slight Relief & 10 & 7 & & & 2 & 6 & & \\
\hline Treatm, Failure & 10 & 16 & & & 6. & 7 & & \\
\hline $\begin{array}{l}\mathrm{CR}+\mathrm{MaR} \\
\text { (Desired Efficacy) }\end{array}$ & 52 & 47 & 1.23 & 0.27 (NS) & 68 & 59 & 3.76 & 0.052 (NS) \\
\hline $\begin{array}{l}\mathrm{CR}+\mathrm{MaR}+\mathrm{MoR} \\
\text { (Success Rate) }\end{array}$ & 80 & 77 & 0.362 & 0.55 (NS) & 92 & 87 & 1.45 & 0.20 (NS) \\
\hline
\end{tabular}

NS $=$ Not Significant

TNSS or NCS produced similar results. At week 4. the desired efficacy based on TNSS was higher than that based on NCS but failed to reach the predetermined level of statistical significance (68 vs 59; $\mathrm{p}=0.052$ ).

The clinical efficacy rates based on physician evaluation are shown in Table 7. The number of patients rated as complete relief were similar either evaluated based on TNSS or NCS at both week-2 and week-4. The success rates also did not differ significantly at both evaluation times. However, the desired efficacy based on TNSS were significantly higher than that based on NCS at both week-2 (50 vs $37 ; \mathrm{p}=0.002)$ and week-4 (73 vs $61 ; \mathrm{p}=0.012)$.
Table 8 shows the improvement of the total symptoms. The patient-rated TSS decreased significantly from a mean of 29.9 to 11.7 at week-2 (a mean reduction of $60.9 \%: p<0.0001$ ), and to 7.7 at week-4 (a mean reduction of $74.2 \% ; p<0.0001$ ). The physician-rated TSS showed similar improvement.

The improvement of the individual symptoms can be seen in Figures 1 and 2, as evaluated by the patient and by the physician, respectively.

Figure 3 shows the improvement of TNSS, NCS and TSS as evaluated by the patient in the morning and in the evening (sum of the last 3 days). The morning symptom scores were consistently higher than the 
Table 7. Clinical efficacy rates based on physician evaluation

\begin{tabular}{|c|c|c|c|c|c|c|c|c|}
\hline & \multicolumn{4}{|c|}{ Week-2 } & \multicolumn{4}{|c|}{ Week-4 } \\
\hline 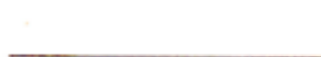 & TNSS & $\mathrm{NCS}$ & $x^{2}$ & $\mathrm{p}$ & TNSS & NCS & $\mathrm{X}^{2}$ & $\mathrm{p}$ \\
\hline $\begin{array}{l}\text { Complete Relief (CR) } \\
\text { Marked Relief (MaR) } \\
\text { Moderate Relief (MoR) } \\
\text { Slight Relief } \\
\text { Treatm. Failure }\end{array}$ & $\begin{array}{r}30 \\
20 \\
33 \\
14 \\
3\end{array}$ & $\begin{array}{l}27 \\
10 \\
40 \\
\cdots \\
23\end{array}$ & 0.444 & 0.51 (NS) & $\begin{array}{r}50 \\
23 \\
21 \\
4 \\
2\end{array}$ & $\begin{array}{r}52 \\
9 \\
30 \\
-- \\
9\end{array}$ & 0.071 & 0.79 (NS) \\
\hline $\begin{array}{l}\mathrm{CR}+\mathrm{MaR} \\
\text { (Desired Efficacy) } \\
\text { CR + MaR + MoR } \\
\text { (Success Rate) }\end{array}$ & $\begin{array}{l}50 \\
83\end{array}$ & $\begin{array}{l}37 \\
77\end{array}$ & $\begin{array}{l}8.47 \\
1.56\end{array}$ & $\begin{array}{l}0.002 \\
0.21(\mathrm{NS})\end{array}$ & $\begin{array}{l}73 \\
94\end{array}$ & $\begin{array}{l}61 \\
91\end{array}$ & $\begin{array}{l}6.05 \\
0.571\end{array}$ & $\begin{array}{l}0.012 \\
0.45 \text { (NS) }\end{array}$ \\
\hline
\end{tabular}

NS $=$ Not Significant

Table 8 . Total symptom score (TSS) before and after treatment

\begin{tabular}{|c|c|c|c|c|c|c|c|c|}
\hline & & \multirow[b]{2}{*}{ Baseline } & \multirow[b]{2}{*}{ Week-2 } & \multirow[b]{2}{*}{ Weck-4 } & \multicolumn{2}{|c|}{$\%$ reduction from baseline } & \multirow[b]{2}{*}{ Paired-t } & \multirow[b]{2}{*}{ p (2-tailed) } \\
\hline & & & & & Week-2 & Week-4 & & \\
\hline \multirow[t]{6}{*}{ a) } & \multicolumn{6}{|c|}{ Patient evaluation (Sum of the last 3 mornings) } & \multirow{6}{*}{$\begin{array}{l}-15.3^{*} \\
-21.0^{* *} \\
-4.33^{* * *}\end{array}$} & \multirow{6}{*}{$\begin{array}{l}<0.0001^{*} \\
<0.0001^{* *} \\
<0.0001^{* *}\end{array}$} \\
\hline & Mean & 29.9 & 11.7 & 7.7 & -60.9 & -74.2 & & \\
\hline & SD & 8.73 & 11.15 & 8.25 & 34.88 & 27.69 & & \\
\hline & Median & 27.5 & 9 & 5 & -68.3 & -81.4 & & \\
\hline & Mode & 26 & 0 & 0 & -100 & -100 & & \\
\hline & Range & $15-51$ & $0-50$ & $0-34$ & $-100 \rightarrow 39.1$ & $-100 \rightarrow 40$ & & \\
\hline \multirow[t]{6}{*}{ b) } & Physicia & uation ( $A$ & orning vi & & & & \multirow{6}{*}{$\begin{array}{l}-17.5^{*} \\
-24.0^{* *} \\
-6.72^{* * *}\end{array}$} & \multirow{6}{*}{$\begin{array}{l}<0.0001^{*} \\
<0.0001^{* *} \\
<0.0001^{* * *}\end{array}$} \\
\hline & Mean & 9.8 & $3.8^{\circ}$ & 2.2 & -61.2 & -77.6 & & \\
\hline & SD & 2.43 & 3.01 & 2.48 & 31,41 & 26.79 & & \\
\hline & Median & 9 & 3 & 1.5 & -66.7 & -87.5 & & \\
\hline & Mode & 9 & 1 & 0 & -100 & -100 & & \\
\hline & Range & $6-17$ & $0-11$ & $0-10$ & $-100 \rightarrow 28.6$ & $-100 \rightarrow 16.7$ & & \\
\hline
\end{tabular}

* Week-2 vs Baseline

NCS and TSS can be seen in Table 9, with the respective percentage reductions from baseline. The percentage reductions of the evening symptom scores were similar to those of the morning scores (see also Tables 2,3 and 8).

\section{Adverse events}

Among 100 patients who received mometasone furoate, adverse events were encountered in 46 patients $(46 \%)$. The total number of adverse events were 73 , of which 41 were considered unrelated to the study drug by the investigator (Table 10). Among 32 adverse events which were considered related, probably related or possibly related to the study drug by the investigator, the most frequent was headache (13 patients), followed by throat abnormalities (6 patients), cough ( 3 patients), myalgia and fatigue ( 2 patients each). Other drug-related adverse events were vomiting, bitter taste, constipation, sneezing, hypertension and pain in the interior septum, which occurred in 1 patient each.

The events were usually considered to be mild to moderate in severity. Only 3 cases were considered severe, of which 2 cases were considered possibly drug-related (headache and sore throat), while another case was considered unrelated to the study drug (total nose obstruction). Most of the events were of short duration (1 to 2 days). Drug-related events with longer 


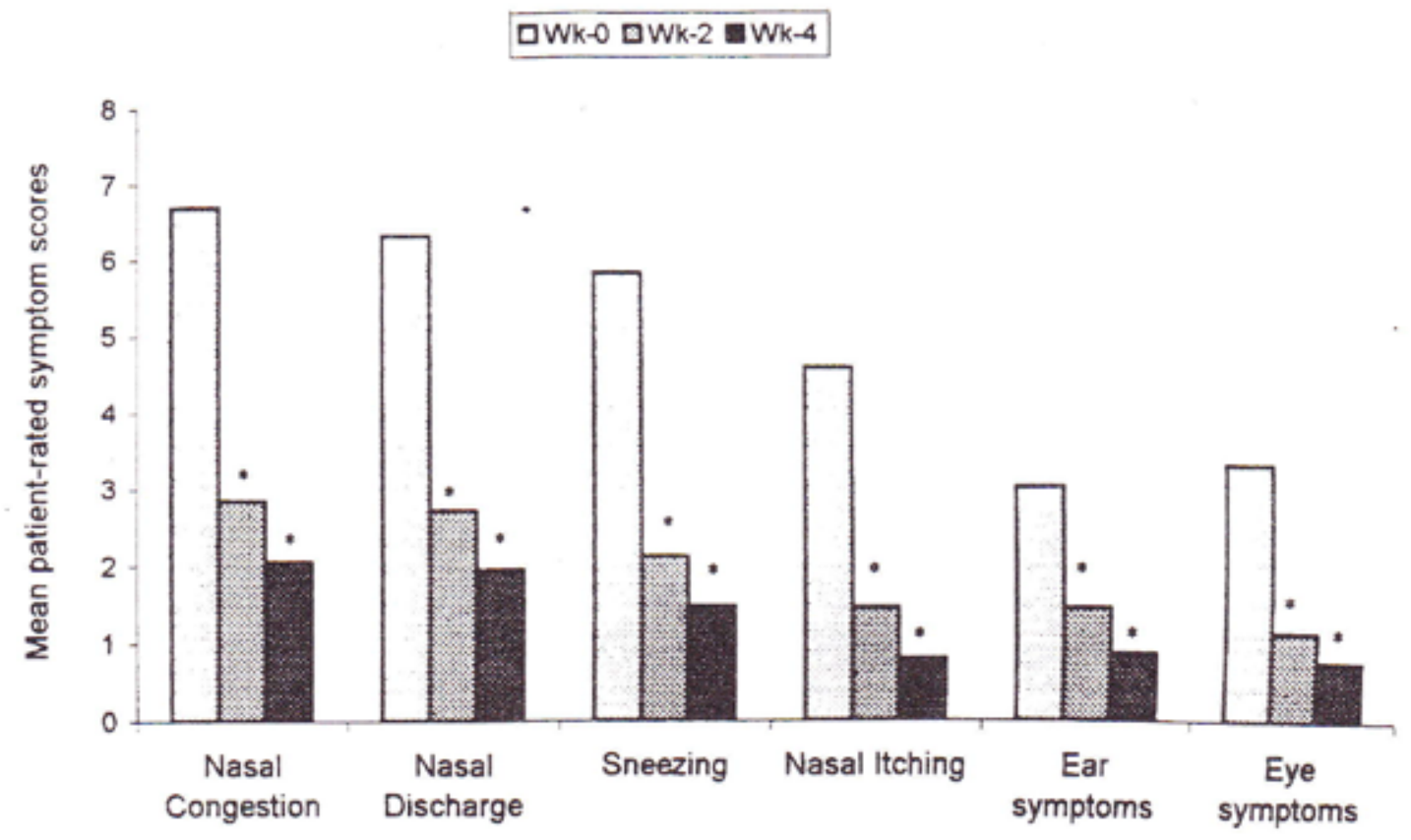

Figure 1. Patient-evaluated individual symptom scores at weeks 0,2 and 4. $* p<0.000 I$ versus week 0



Figure 2. Physician-evaluated individual symptom scores at weeks 0,2 and 4. ${ }^{*} p<0.0001$ versus week 0 




Figure 3. Morning and evening patient-evaluated symptoms at weeks 0,2 and 4 . ${ }^{*} p<0.0001$ versus week-0

Table 9. Patient-evaluated evening TNSS, NCS and TSS (mean values)

\begin{tabular}{|c|c|c|c|c|c|c|c|}
\hline & \multirow[b]{2}{*}{ Baseline } & \multirow[b]{2}{*}{ Week-2 } & \multirow[b]{2}{*}{ Week-4 } & \multicolumn{2}{|c|}{$\%$ reduction from baseline } & \multicolumn{2}{|c|}{ p (2-tailed) } \\
\hline & & & & Week-2 & Week-4 & W2 vs W0 & W4 vs W0 \\
\hline a) & $\begin{array}{c}\text { Evening TNSS } \\
21.0\end{array}$ & 8.0 & 4.8 & -61.9 & -77.1 & $<0.0001$ & $<0.0001$ \\
\hline b) & $\begin{array}{c}\text { Evening NCS } \\
6.34\end{array}$ & 2.64 & 1.72 & -58.4 & -72.9 & $<0.0001$ & $<0.0001$ \\
\hline c) & $\begin{array}{c}\text { Evening TSS } \\
27.0\end{array}$ & 10.6 & 6.3 & -60.7 & -76.7 & $<0.0001$ & $<0.0001$ \\
\hline
\end{tabular}

duration : 3 cases (headache, throat irritation, vomiting) lasted 3 days, and 14 cases ( 4 cases of headache, 4 cases of throat abnormalities, 2 cases of cough, and 1 case each of myalgia, sneezing, bitter taste and constipation) persisted for 4 days or more. There was no withdrawal due to adverse event.

\section{DISCUSSION}

The results of the present study demonstrate the clinical efficacy and tolerability of mometasone furoate, at a dose of $200 \mu \mathrm{g}$ once daily in the morning, in patients with moderate to severe perennial allergic rhinitis in a tropical country.

Most of the study patients were young adults (mean 27.3 years) and allergic to more than one major allergen for PAR, especially house dust and house dust mites (confirmed by skin prick test) with a mean duration of 6.2 years. In previous studies of MF in the treatment of PAR, ${ }^{6,7}$ the patients were also young adults but somewhat older (means 33-34 years) with longer duration of PAR (means 12-13 years). 
Table 10. Adverse events

\begin{tabular}{|c|c|c|c|}
\hline Adverse event & $\begin{array}{l}\text { No. of patients experiencing } \\
\text { the } \mathrm{AE} \text { at least once }\end{array}$ & $\begin{array}{l}\text { No. of patients } \\
\text { the } \mathrm{AE}-\text { drug } \\
\text { unrelated* }\end{array}$ & $\begin{array}{l}\text { No. of patients } \\
\text { the } \mathrm{AE}-\text { drug } \\
\text { related** }\end{array}$ \\
\hline Headache & 31 & 18 & 13 \\
\hline Cough & 5 & 2 & 3 \\
\hline $\begin{array}{l}\text { Throat abnormalities } \\
\text { (sore, dry, irritating, } \\
\text { itching, painful, obstructed) }\end{array}$ & 6 & -. & 6 \\
\hline Myalgia & 3 & 1 & 2 \\
\hline Fatigue & 2 & -. & 2 \\
\hline $\begin{array}{l}\text { Vomiting, bitter taste, constipation, } \\
\text { sneezing, hypertension } \\
\text { pain in the anterior septum }\end{array}$ & 1 each & -. & 1 each \\
\hline Fever & 4 & 4 & .. \\
\hline Gastritis & 3 & 3 & .. \\
\hline Toothache & 3 & 3 & .. \\
\hline Dyspnea & 2 & 2 & .. \\
\hline Common cold & 2 & 2 & -. \\
\hline $\begin{array}{l}\text { Rhinorrhea, total nose obstruction } \\
\text { swollen eyes, urticaria, } \\
\text { hyperhydrosis, dysmenorrhea }\end{array}$ & I each & 1 each & - \\
\hline Total & 73 & 41 & 32 \\
\hline
\end{tabular}

* No. of patients in whom the AE was considered unrelated to the study drug by the investigator

** No, of patients in whom the AE was considered either related, probably related or possibly related to the study drug by the investigator.

The mean body weight in the present study was 52.8 $\mathrm{kg}$, while in previous studies, ${ }^{6.7}$ the patients were heavier (means 74 and $69 \mathrm{~kg}$ ). Since the dose of MF was the same $(200 \mu \mathrm{g} /$ day $)$ in these 3 studies, the dose per $\mathrm{kg} \mathrm{BW}$ was higher in our study $(3.8 \mu \mathrm{g} / \mathrm{kg} /$ day $)$ than in the other studies ( 2.7 and $2.9 \mu \mathrm{g} / \mathrm{kg} /$ day).

The present results showed the close agreement between percentage reductions in symptom scores evaluated by the patient and those evaluated by the physician (see Tables 2, 3 and 8). In previous studies, ${ }^{6.7}$ the percentage reductions evaluated by the physician were always higher than those evaluated by the patient, especially at week 2 (10\% or more); the difference became closer at week 4 . This was due to different values that were selected as patientevaluated scores : while in the previous studies all daily scores were used, the present study used only the last 3-day scores, and therefore very close to the score on the visit day which was evaluated by the physician. This was especially true during the first 2 weeks when the drug just started to work. Meanwhile, physician-evaluated scores were obtained in similar situation in all of the studies, including the present study, and therefore can be used for comparison among these studies.

The percentage reductions in physician-rated TNSS in the present study (means $61.7 \%$ at week-2 and $77.8 \%$ at week-4) were higher than those in the previous studies (means as estimated from figures were $43 \%$ and $51 \%$ at week-2, $52 \%$ and $54 \%$ at week-4). ${ }^{6.7}$ The continuing improvement of TNSS values with time was clearly seen in these 3 studies. The previous 2 studies showed that the improvement reached a plateau after 4-6 weeks of treatment, and therefore a study of 4 weeks duration may be considered sufficient.

The individual nasal symptom scores followed a similar pattern as that of TNSS (see Figures 1 and 2), as already shown by Mandl et al. ${ }^{7}$ Individual nonnasal symptom scores, also showed a pattern similar to the nasal symptom scores (Figures 1 and 2). As predicted, the percentage reductions in TSS were similar to those in TNSS, showing that the non-nasal symptoms follows closely the nasal symptoms. 
The percentage reductions in physician-rated NCS in the present study (mean $53.9 \%$ at week- 2 and $73.7 \%$ at week-4) were higher than in Mandl's study (mean $53 \%$ at week-4 and $56 \%$ at week- 8$)^{7}$ In the present study, the percentage reductions in NCS (Table 3) seemed to be somewhat lower than those in TNSS (Table 2) as evaluated by both the patient and the physician. This may indicate that nasal congestion is more difficult to be relieved than the other nasal symptoms. $\mathrm{Mandl}^{7}$ has showed that at week 8 , the physician-rated percentage reduction of nasal congestion by MF was $56 \%$ while that of nasal discharge was $64 \%$. The patient-rated percentage reduction of NCS was also consistenthy lower compared to those of other nasal symptoms along this 12 -week study. ${ }^{7}$

In the present study, the proportion of patients demonstrating complete relief (CR) or marked relief (MaR) based on physician-evaluated TNSS was $50 \%$ at week-2 and $73 \%$ at week-4 (Table 4). These figures were higher than those found in the previous studies : $53 \%$ at week- $8^{6}$ and $69 \%$ at week- $12 .^{8}$

The similar percentage reductions in TNSS as evaluated by the patient and the physician in the present study (Table 2) was reflected by the similar proportions of patients showing $\mathrm{CR}$ or $\mathrm{MaR}$ at both week- 2 and week-4 (Table 4). The similar percentage reductions in NCS (Table 3) was also reflected by the similar proportions of patients showing $\mathrm{CR}$ or MaR (Table 5).

The higher proportion of patients showing $\mathrm{CR}$ or MaR based on TNSS than NCS at week-4 as evaluated by the patient (see Table 6) and at both weeks 2 and 4 as evaluated by the physician (see Table 7) supports the above suggestion that nasal congestion is more difficult to be relieved than the other nasal symptoms.

The higher percentage reductions in physician-rated TNSS and physician-rated NCS, and also in the proportion of patients demonstrating $\mathrm{CR}$ or $\mathrm{MaR}$ in the present study than those observed in the previous studies suggests that MF nasal spray may be more effective for PAR patients in tropical countries than in 4-season countries. However, climate may not be the only factor contributing to the higher efficacy in the present study. Other factors, such as the sensitivity of our patients, and the higher dose used per $\mathrm{kg} \mathrm{BW}$ in our study $(3.8 \mu \mathrm{g} / \mathrm{kg} /$ day vs 2.7 and $2.9 \mu \mathrm{g} / \mathrm{kg} /$ day), may also have some contributions. The possibility that our patients were more sensitive to MF cannot be excluded, while the contribution of the higher dose used per $\mathrm{kg} \mathrm{BW}$ is less likely considering the fact that the dose response has reached a plateau at $200 \mu \mathrm{g}$ dose, the dose used in the present and previous studies.

The observation in the present study that the mean evening diary scores were lower than the morning scores (Figure 3) conforms to the previous observation that in the majority of patients with allergic rhinitis, the nasal symptoms are most severe in the morning. ${ }^{10}$ Similar mean reductions of the evening diary scores as compared to those of the morning diary scores (Tables 2, 3 and 9) indicated that MF administered once daily in the morning provides 24-hour control of nasal symptoms. The same results were provided by previous studies. ${ }^{6,7}$

The incidence of drug-related adverse events in the present study was $32 \%$, this was similar or somewhat lower than that observed in two previous studies : $33 \%$ and $43 \%,{ }^{6,7}$ The marked difference was the absence of epistaxis in the present study, while in previous studies it was the most frequent treatmentrelated $\mathrm{AE}$ : 14-19 \%. ${ }^{6,7,11}$ Epistaxis has been associated with chronic use of placebo nasal sprays; ${ }^{12}$ the incidence of epistaxis in the placebo group in the aforementioned studies ranged from 6 to $11 \%$. Therefore the absence of epistaxis in the present study may because our patients were still naïve in the use of nasal sprays. The most frequent drug-related $\mathrm{AE}$ in the present study was headache $(13 \%)$. Headache was the second most frequent treatment-related $\mathrm{AE}$ in the other studies, with an incidence of 6 to $10 \%{ }^{6.7}$ The absence of withdrawal indicated that the use of MF aqueous nasal spray was well tolerated, which is in accordance with previous results. ${ }^{6-8}$

In conclusion, MF aqueous nasal spray, at a dose of $200 \mu \mathrm{g}$ once daily in the morning for the treatment of moderate to severe PAR in a tropical country, was clinically effective with 24-hour control of PAR symptoms, and was well tolerated.

\section{Acknowledgements}

We thank the study patients for their cooperation, the study personnel for their commitment, and ScheringPlough Indonesia for funding the study.

\section{REFERENCES}

1. Mometasone furoate aqueous nasal spray investigator's brochure. Schering-Plough, 1999. 
2. Onrust SV, Lamb HM. Mometasone furoate : a review of its intranasal use in allergic rhinitis. Drugs 1998; 56 (4) : 725-45.

3. Naclerio RM. Allergic rhinitis. NEJM 1991; $325: 860-9$.

4. Lund V. International Consensus Report on the Diagnosis and Management of Rhinitis. Allergy 1994; 49 (Suppl 19) : 5-34.

5. Clin Doc 98264650. One-year, double-blind study of the effects of mometasone furoate nasal spray versus placebo on growth of children with perennial rhinitis [study report for protocol C 96-094]. Kenilworth (NJ, USA) : ScheringPlough Research Institute; 1998 Sep.

6. Drouin $\mathrm{M}$, Yang WH, Bertrand B, Van Canwenberge P, Clement $\mathrm{P}$, Dalby $\mathrm{K}$, et al. Once daily mometasone furoate aqueous nasal spray is as effective as twice daily beclomethasone dipropionate for treating perennial allergic rhinitis patients. Ann Allergy Asthma Immunol 1996; $77: 153-60$.

7. Mandl M, Nolop K, Lutsky BN, et al. Comparison of once daily mometasone furoate (Nasonex) and fluticasone propionate aqueous nasal sprays for the treatment of perennial rhinitis. Ann Allergy Asthma Immunol 1997; 79 : 370-45.

8. Day J, Nolop K, Lutsky BN, et al. Comparison of once daily treatment with mometasone furoate (Nasonex ${ }^{\mathrm{TM}}$ ) and fluticasone propionate aqueous nasal sprays for the treatment of perennial rhinitis. [Abstract]. J Allergy Clin Immunol 1997; 99 : S441.

9. Bronsky EA, Aaronson DW, Chervinsky P, Graft D, Kaiser HB, Moss B, et al. Dose ranging study of mometasone furoate (Nasonex) in seasonal allergic rhinitis. Ann Allergy Asthma Immunol 1997;79(1): 51-6.

10. Bryson HM, Faulds D. Intranasal fluticasone propionate. A review of its pharmacodynamic and pharmacokinetic properties, and therapeutic potential in allergic rhinitis. Drugs 1992; $43: 760-75$.

11. Bernstein DI, Nolop K, Mesarina-Wicki B. Evaluation of mometasone furoate (Nasonex ${ }^{\mathrm{TM}}$ ) nasal spray in perennial rhinitis. [Abstract]. Ann Allergy Asthma Immunol 1997; 78: 154.

12. Simons FER, Simons KJ. Optimum pharmacological management of chronic rhinitis. Drugs $1989 ; 38: 313-31$. 